
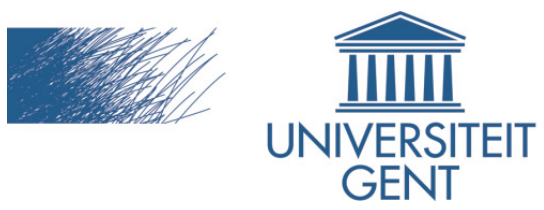

biblio.ugent.be

The UGent Institutional Repository is the electronic archiving and dissemination platform for all UGent research publications. Ghent University has implemented a mandate stipulating that all academic publications of UGent researchers should be deposited and archived in this repository. Except for items where current copyright restrictions apply, these papers are available in Open Access.

This item is the archived peer-reviewed author-version of:

Oiling global capital accumulation: analysing the principles, practices, and geographical distribution of Islamic Financial services

Bassens, D.; Derudder, B.; Witlox, F.

In: The Service Industries Journal, 31 (3), p. 327-341, 2011.

doi: $10.1080 / 02642060802712830$

To refer to or to cite this work, please use the citation to the published version:

Bassens, D.; Derudder, B.; Witlox, F. (2011). Oiling global capital accumulation: analysing the principles, practices, and geographical distribution of Islamic Financial services. The Service Industries Journal, 31 (3), p. 327-341. doi 10.1080/02642060802712830 


\title{
OILING GLOBAL CAPITAL ACCUMULATION: ANALYZING THE PRINCIPLES, PRACTICES AND GEOGRAPHICAL DISTRIBUTION OF ISLAMIC FINANCIAL SERVICES
}

\author{
David Bassens, Ben Derudder, Frank Witlox
}

\begin{abstract}
This article focuses on the Islamic financial services (IFS) sector, which originated in the Middle East, but is now fast becoming a global sector. First we discuss Islamic economic ideology, which resulted in the foundation of IFS firms after the 1973 oil crisis. The second part provides an overview of the most common IFS. The third part discusses the global distribution of IFS firms and Shari'a compliant assets. The Middle East is at the apex of the IFS sector, with the Islamized economies of Iran and Pakistan and prime hubs such as Manama and Dubai. Outside the Middle East, Malaysia is identified as an important growing market for IFS, while outside the Muslim world London is increasingly profiling itself as a global IFS hub.
\end{abstract}

\section{Introduction}

Some recent trends and events in the world economy have given rise to a number of farreaching considerations regarding the implications of the use of some financial instruments and the concomitant consequences for the global economic system as a whole. For instance, the often speculative trading of securities and the use of numerous types of 'exotic' derivatives has seriously altered the face of international finance in the last decades. A major consequence of this evolution is that much of the world economy seems to have taken a virtual, highly intangible character. Although in principle enlarging the economic potential, this move away from the 'real' commodity-based economy has recently shown to be risk-infested to say the least. In an intensely integrated economy, a 'local' crisis can easily spread to become a malaise on a global scale, as is currently illustrated by the global credit-crisis following the 2008 sub-prime lending in the United States (Taylor et al., 2009).

Parallel to these fundamental economic concerns, investors are increasingly sensitive about the moral implications of their investments. The fact that in recent years numerous ethical investment funds have arisen clearly indicates that public opinion throughout the world is giving a signal that profit cannot be the only goal of investments. Financial institutions have therefore come up with an array of funds banning investment in 'unethical' activities such as industries of weapons, tobacco, gambling, etc.

Apart from the ethical dimensions of investment behaviour, moral concerns are often based explicitly on religious grounds, and they are by no means constraint to 'Western' financial circuits. In fact, within the Muslim world ${ }^{1}$ and especially within the Middle East, scholars and financial experts have since long been sensitive to both the economic and moral aspects of the financial system. Combining a distinct view on an interest-free economy and a clear vision on virtuous and prohibited investments, the Islamic financial services (IFS) sector has known a rapid growth since the 1970s. Although Islamic economics had been conceptualized early in the $20^{\text {th }}$ century, it was only from the 1970 s onwards that the Muslim world, and especially the oilexporting countries in the Middle East, established the financial basis that allowed for the actual 
implementation of this rationale. Indeed, in spite of some experiments in rural areas of Egypt in the 1960s, the rise of IFS can be traced back to the two oil-price shocks in the $1970 \mathrm{~s}^{2}$, which led to a massive transfer of wealth from oil-consuming to oil-producing countries, of which many were located in the Middle East (Akacem and Gilliam, 2002; Tripp, 2006). This excess income found its way in the interest-based system through 'conventional' banks throughout the world (but mainly headquartered in Europe and the United States), but it also resulted in the emergence of a number of new Islamic financial institutions and instruments within the region. Despite rather meagre results in absolute terms in the early years, the IFS sector has been rapidly expanding recently, with annual growth rates of $15 \%$ to $20 \%$. This success has undoubtedly been fuelled by a general 'Islamic revival' within the Middle East. As the second oil shock coincided with the Iranian revolution and the emergence of the first Islamic republic, Islamic banking and finance increasingly came to be regarded as the 'appropriate' way to do business for Muslims seeking an alternative consistent with Islamic teaching (Akacem and Gilliam, 2002). Nowadays, given the overall rising trend of oil prices, the financial basis for IFS seems assured. While the current IFS market is rather limited ${ }^{3}$ with an estimated size of 639 billion US\$ (The Banker, 2008: 3), Standard \& Poor's has claimed that the potential market for Islamic finance could be 4 trillion US\$, over six times its current size (IFSL, 2008: 1).

The objective of this paper is to discuss the key characteristics of the IFS sector. It is hereby our intention to show that the global influence of the IFS sector is rapidly growing, not only as an ethical niche, but also as the vanguard of a full-scale emerging market in which international financial centres - both in the Middle East and elsewhere - are anxiously trying to play a decisive role. The paper is structured as follows. In a first section we discuss the Islamic economic rationale and its origins. The second section provides an overview of the ways in which this overarching economic rationale is put to practice within the fast growing IFS sector, while the third section aims to locate these practices on the world map.

\section{The origins of Islamic financial services in Islamic economics}

While in many studies on IFS the emphasis is generally on their economic aspects, Islamic economics actually originated in the Muslim world as an ideological paradigm, embedded within a context of regional and national struggles for political power and a search for a distinct 'Islamic' identity (Kuran, 1995, 1997). From the 1940s onwards, the Middle East saw the advent of Islamic economics as a claimed ideological alternative to existing paradigms. As Muhammad Baqir al-Sadr (1931-1980), a famous Iraqi Shi'i jurist saw it at the time, Islamic economics could be an alternative for the models of capitalism and Marxism as an entirely separate system (Ala Hamoudi, 2007). As a modern, all-encompassing model for social, economic, and political life, Islamic economics claimed to be "the Third Way" and an alternative to Western economic conceptions. It was thought to avoid the inegalitarian excesses of modern capitalism, while at the same time unleashing the energies of entrepreneurs and merchants (Hefner, 2006: 17). In essence, Islamic economics was aimed at freedom from colonial rule, exploitation, and oppression through a return to Islam, which stood for the elimination of poverty and the reduction of unequal distribution of wealth (Siddiqi, 2007: 99-100).

However, according to other authors (e.g., Kuran, 1995), the onset of Islamic economics in itself was not rooted in the claimed intentions to change economic imbalances, injustices or 
inequalities. Instead, it must be framed within the specific historical situation of Indian Muslims in the 1940s, who wanted to defend Islamic civilization against foreign cultural influences. As Kuran (1997: 302, original emphasis) notes: 'the economics of Islamic economics was merely incidental to its Islamic character'. For instance, the Pakistani ideologist Sayyid Abul A'la Maududi (1903-1979), popularized the term 'Islamic economics' because he saw economics as a vehicle for (re)establishing Islamic authority in a domain where Muslims were falling increasingly under the influence of Western ideas.

The religious foundations for this Islamic ideological reassertion were provided by the prime sources of Islam i.e. the Koran and the hadiths ${ }^{4}$. These two sources are the basis of the Shari'a, the Right Path and the Holy Law of Muslims. In addition, Islamic reasoning is based on analogy, and the consensus of the Islamic religious scholars (ulama). Muslims attune their actions to the Shari'a, which comprises a set of ideas and rules that regulate the relation between man and God and between man and fellow man. As the distinction between actions that are Shari'a compliant (halal) and Shari'a prohibited (haram) plays a crucial role in all Muslim behaviour, it evidently affects all economic activities as well.

Based on the above-mentioned evolutions, Islamic economics started to promote a distinct rationale which prohibits three aspects of conventional interest-based economics: riba (interest), gharar (uncertainty), and maysir (gambling) (Bassens et al., 2010). In addition, Islam forbids the trading and consumption of an array of products that are haram (i.e. pork meat, alcohol, pornography, weaponry, gambling). The first feature, the prohibition of riba ('increase' or interest) is probably the most widely known. In Islamic thought, time does not equal money. Since money is not considered a commodity, but rather a bearer of risk (Pollard and Samers, 2007: 315), there is a strong belief that money should not make money by itself. In an interestbased system, an entrepreneur borrowing money from a 'conventional' bank has to pay up every term, regardless of the profits or losses he has made. From an Islamic point of view, the fact that one party could earn a profit while his business project partner suffers a loss, is considered highly inequitable. Profit-and-loss sharing between commercial parties is therefore considered the alternative to the interest-based system, thus guaranteeing social harmony (Ala Hamoudi, 2007). For instance, in the case of a loan, a money lender does not earn money simply by lending it to the borrower. Instead, a money lender can get an extra return in the form of a pre-agreed part of the profits, or take the loss by ratio of the investment. By prohibiting the raising of interest, the Islamic economic rationale prevents the occurrence of disproportionate losses and gains, thereby aiming to enhance social cohesion.

Second, the prohibition of gharar is referring to acts and conditions in exchange contracts, of which the full implications are not clearly known to the parties and could lead to exposing one of the parties to unnecessary risks (Iqbal and Molyneux, 2005: 14). For instance, one speaks of gharar if (i) the parties lack knowledge; (i) the object does not exist; or (iii) the object evades the parties' control (Vogel and Hayes, 1998: 89-90). The word gharar means deception or delusion, but also connotes peril, risk or hazard. In financial terms, it is interpreted as 'uncertainty, risk or speculation' (Warde, 2000: 59). In essence, the prohibition on gharar rejects any gain that may result from chance or undetermined causes. Therefore, there is a ban on the sale of an item that does not exist yet, and also on contracts with uncertainty about their cost and duration (Sanhuri, 1967: 31, 49). Gharar thus refers to the exploitation that can arise from contractual ambiguities, and its prohibition therefore aims to eliminate or at least minimise this legal risk. However, the 
prohibition of gharar does not imply that literally all risks are banned: the accepted salam contract, where one party provides a loan and the other party promises to procure commodities, is a good example of the latter (Bekkin, 2007b: 23). As the price of the commodities may drop after the contract was closed, some risk is inevitably transferred to the money lender. At the same time, however, the lender may reap the benefits of a good price if prices have gone up after the contract was closed. Gharar is therefore in essence about eliminating excess risk, and sharing entrepreneurial risk between parties in a contract. Islam does however not reject all forms of risk-taking: the risk one takes when investing in a project is even encouraged. As Iqbal and Molyneux (2005: 15) put it:

"Entrepreneurial risk [...] is part of the normal course of business. Every economic activity involves uncertainty which generates risks. Some agents, called entrepreneurs, take those risks. An enterprising person makes profit, and on occasion incurs losses [...] Willingness to take such risks does not imply any moral evil; rather, it is a need that no society can do away with."

Meanwhile, the rejection of excessive risk-taking not only influences the making of a contract, but also highly restricts the further trading of contracts, be it via futures, options, swaps and other derivatives (see Naughton and Naughton, 2000). In the case of future contracts, the Islamic al-istisna (contract) provides means for future delivery, but only if the delivery is actually made. The problem with conventional futures is that the commodity is seldom (or never) delivered to the other party. Instead, these futures are traded on the exchange, and used for speculative reasons. As for stock options, both short selling and the use of put and call options is evidently speculative and therefore haram.

The third prohibition, the one of maysir, is very much related to the above-mentioned concept of gharar. It bans all kinds of gambling and games of chance, but equally rejects all forms of speculation (which can be thought of as gambling). Games are considered unnecessary for a person and for society as a whole, since no economic value is added to the wealth of society (Iqbal and Molyneux, 2005: 15). Since maysir is often related with high levels of uncertainty, the difference with gharar may sometimes seem relatively vague. However, whereas a degree of gharar is inherent to economic activities and is thus acceptable, maysir is completely banned by Islam. 


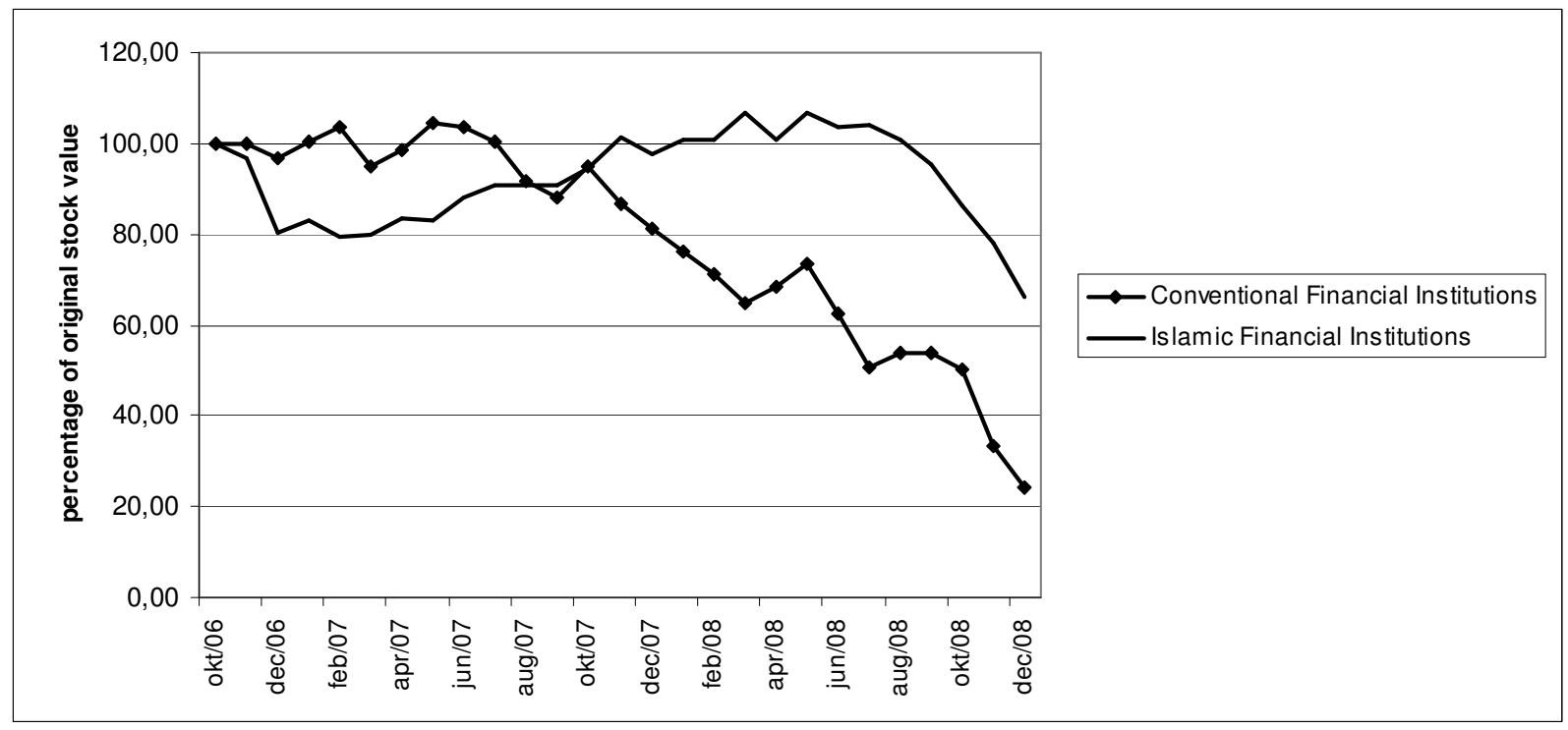

Figure 1 Combined stock evolutions of the top 10 conventional financial services firms from Octobre 1 st 2006 (100 \%) until December 1st 2008 (FI: ING Group, Fortis, Citigroup, Dexia Group, HSBC Holding, BNP Paribas, Crédit Agricole, Deutsche Bank, Bank of America Corp., UBS) and top 10 listed IFS firms (IFI: Al Rahji Bank, Kuwait Finance House, Dubai Islamic Bank, Blom Bank, Abu Dhabi Islamic Bank, Al Baraka Banking Group, BIMB Holdings, Bank Alfalah, Bank Al Jazira, Qatar Islamic Bank).

Bearing these differences in mind, it can be expected that IFS firms - which have largely developed in isolation from the global interest-based financial system with all its risk-taking will suffer less from global crises. This assumption seems to be correct at time of writing, as Figure 1 shows. The figure compares the combined stock evolution of the top 10 'conventional' financial services firms (based on Fortune's Global 500) with the top 10 of listed IFS firms, for the last two years.

This comparison suggests that IFS firms have been substantially less affected by the fastspreading global financial crisis. While the leading 'conventional' financial stocks have dropped over $75 \%$, the IFS firms' stocks have kept $66 \%$ of their initial value. Furthermore, since last year the global amount of Shari'a compliant assets has risen with 27,6\% (The Banker, 2008: 3). In the long run, however, the IFS sector's oil dependence could very well drag these firms further down. Indeed, given the high oil prices in the spring of 2008, soaring to as much as 145 US\$ per barrel, the sector's position had remained untouched. Now, with oil prices dropping fast towards the end of 2008, it is likely that the financial crisis will eventually hit the IFS sector as well. Time will tell if the IFS sector will turn out to be a safe haven for global investors, and a shelter for the global financial downturn.

\section{Islamic economics in practice: Islamic banking, finance and insurance}

Based on the overarching rationale of Islamic economics, a whole array of Shari'a compliant financial products has emerged in the last decades, predominantly in retail, although the wholesale Islamic finance market is also growing as IFS firms are increasingly going global. The next section discusses these globalization startegies in detail, here we focus on the retail side of the IFS sector, i.e. the products offered in the field of Islamic banking and insurance. We discuss two models of Islamic banking (see Table 1): while the two-tiered mudarabah model describes an ideal situation, the one-tiered mudarabah model is more consistent with actual practice. 
Furthermore, this section also briefly discusses the use of 'benevolent loans' (Qard al-Hasanah) by Islamic banks and the way IFS firms organize Islamic insurance (takaful) for their customers.

\subsection{A Two-tiered Mudarabah as an 'Ideal' Islamic Banking Model}

An ideal model of Islamic banking involves a two-tier mudarabah system, implementing passive partnership on both liabilities and asset side. On the liabilities side of the bank, the depositors supply the capital for the joint stock company and in the case of investment deposits they become shareholders in the bank (Iqbal and Molyneux, 2005: 19). Islamic banks raise their funds through two types of deposits: transaction deposits and investment deposits (Khan and Mirakhor, 1990: 354-355). Transaction deposits resemble conventional demand deposits. They often follow the principle of wadiah according to which the depositor agrees to deposit an asset, excluding immovable fixed assets, in the custody of another party that is not the owner (Sudin et al., 1994: 33). Although the bank guarantees the nominal value of the transaction deposit, no returns are paid on these liabilities. Investment deposits on the other hand constitute the principle source of funds. These deposits are best to be compared with conventional shares rather than conventional savings deposits. The bank does not guarantee their nominal value, nor does it pay a fixed return. Rather, the depositors are treated as shareholders of the bank, who are entitled to a share of the profits or losses made by the bank (Khan and Mirakhor, 1990: 354$355)$.

Table 1 Two models of Islamic Banking

\begin{tabular}{|c|c|}
\hline & \multirow{2}{*}{$\begin{array}{l}\text { Assets } \\
\begin{array}{l}\text { 1. Two-tier mudarabah } \\
-\quad \text { Mudarabah financing (PLS) }\end{array}\end{array}$} \\
\hline \multirow{3}{*}{$\begin{array}{l}\text { Mudarabah: } \\
\quad \text { Transaction deposits (nominal value } \\
\quad \text { guaranteed, no returns) } \\
\text { - } \quad \text { Investment deposits (nominal value not } \\
\quad \text { guaranteed, PLS) }\end{array}$} & \\
\hline & $\begin{array}{cl}\text { 2. One-tier mudarabah } \\
-\quad \text { Musharakah financing (PLS) } \\
-\quad \text { Murabahah (mark-up) } \\
-\quad \text { Ijarah (mark-up) } \\
-\quad \text { Salam (mark-up) } \\
-\quad \text { Al-Istisna (mark-up) }\end{array}$ \\
\hline & Qard al-Hasanah (benevolent loans) \\
\hline
\end{tabular}

On the asset side, the bank acts as an investor in numerous public and private projects. The bank hereby acts as the capital owner investing the money of its depositors in a project. These investments are managed by the entrepreneur, who does not invest his own money in the project. The profits of the enterprise are shared between the partners at an agreed ratio. In case of losses, the bank takes the total burden, while the entrepreneur loses his employment, and simply does not reap the benefits of his efforts. These types of investments are usually on a short term. The profits gained from these projects - after deducting the agent (wakil) costs of the bank - are redistributed among the depositors at a pre-agreed ratio. The ideal two-tiered mudarabah model thus involves profit-and-loss sharing at both the asset and liabilities side of the bank. By consequence, in the case of loss on investment, the losses are shared both by the bank and the depositors, which is rather unusual from a 'conventional' point of view. 


\subsection{A One-tier Mudarabah Model in Combination with Profit-and-Loss Sharing (PLS) and Mark-up Products}

Although the two-tiered mudarabah is regarded as an ideal model of Islamic banking, it is in fact implemented by very few Islamic banks. This is mainly due to an array of issues surrounding the use of mudarabah on the asset side. For instance, since the PLS principle transfers a substantial share of the risk to the Islamic bank, the screening costs and the monitoring of investments are generally higher. In addition, the fact that profits are shared between the bank and the money lender implies that a moral hazard problem can arise, since the lender can take a share of the profits before the PLS mechanism is started. Generally then, a one-tier mudarabah system on the liability side is combined with a broad range of financial products on the asset side (see Iqbal and Molyneux, 2005: 19-26). While musharakah is equally based on PLS, the lion's share is based on mark-up principles (murabahah, ijarah, salam, and al-istisna). Musharakah is the only PLS alternative to mudarabah and can be compared to a joint enterprise in conventional terms. Whereas mudarabah implies that the bank is passive partner, here the bank takes an active management role.

Most of the Islamic products, however, are based on mark-up, while mudarabah and musharakah represent only a small percentage (ca. 5\%, see Pollard and Samers, 2007: 315) of financing by Islamic banks. One of the most common mark-up products is murabahah. The standard procedure involves the bank buying a commodity for the client, which is then sold to the client at a higher price. This actually reflects a deferred payment at a prefixed price, where the amount is paid in a lump sum or in instalments. This contract seems to have a lot in common with a conventional loan at a fixed interest rate. The difference, from the banks point of view, is that it is not making money with money, but that it is being rewarded for the services provided and risks run.

Another mark-up product is ijarah, which is comparable to conventional leasing products. Further, salam and al-istisna are the most common mark-up products in trade financing. While in both cases the delivery is deferred, al-istisna can also defer the actual payment, provided it was fixed at the time of contracting. In these trade contracts, the commodities or services must be delivered to make the contract be Shari'a compliant. Otherwise a situation of futures trading can emerge, while the trade in financial derivates is mostly considered as unlawfully (Goldberg, 2004).

\subsection{Qard al-Hasanah}

Perhaps the most surprising mode of financing from a conventional perspective is finance through benevolent loans. The so-called qard al-hasanah are provided by the bank without the obligation of paying for the loan. The initial capital must be returned, but no extra fee is charged. However, if the enterprise turns out to be fruitful, the client may decide to pay the bank a reward for the loan he or she received. (Iqbal and Molyneux, 2005)

\subsection{Islamic insurance: takaful}

Apart from the above-mentioned banking services, Islamic insurance has gained enormous popularity in the last few years. Takaful, literally 'guaranteeing each other', forms the basis of Islamic insurance (Bekkin, 2007b: 109). Apart from the excessive risks induced by gharar and 
maysir, there is always the possibility that natural disasters and calamities occur. Since the latter cannot be avoided insurance is considered a good thing since it gives people the means to protect themselves against these uncertainties. However, insurance cannot be organized through 'conventional' insurance companies as they are reinvesting premiums on an interest basis, which of course conflicts with the Islamic perspective on riba. In answer to these restraints, Islamic insurance companies offer takaful insurance, which are very much organized like 'conventional' mutual insurance funds (see Bekkin, 2007b). Takaful is set up as a communal fund made up of the contributions of all participants. All claims are paid from this fund, so the risks are borne collectively. The takaful fund is based on the mudarabah principle, so any surpluses at the end of a term are divided among the participants at a pre-agreed profit-sharing ratio. However, in the case of shortages, the participants are expected to pay an additional premium.

\section{The geography of Islamic financial services}

While the previous section has discussed the retail side of the IFS sector, this section focuses on the observation that the IFS sector is increasingly 'going global'. This section therefore provides a brief overview of the IFS sector, focusing on both the geographical distribution of Shari'a compliant assets and the location of the top firms in the business. Since the IFS sector has evolved from a distinct Islamic economic rationale that originated in the Muslim world, the biggest part of the 639 billion US\$ Shari'a compliant assets is evidently located in the Middle East, mainly in the field of retail services to Muslim customers. However, IFS firms are increasingly 'going global', offering their products to customers in non-Muslim countries in Europe and North America. In addition to the growing retail side, a wholesale secondary market in Islamic asset-backed securities is starting to flourish within the Gulf region, absorbing excess liquidity into real estate and major infrastructure projects. These mega projects are increasingly financed through tradable sukük, an evolution that clears the horizon for a regional or even global Islamic secondary market.

First, to get an idea about the basic geography of the globalized IFS sector, Table 2 provides an overview of the spatial distribution of Shari'a compliant assets, both globally and within the Gulf Cooperation Council (GCC) states. Based on a listing of 500 Islamic financial institutions (The Banker, 2008), it can be seen that the biggest share (ca. 41\%) of the worlds Shari'a compliant assets is located in the GCC states, followed by the non-GCC MENA (Middle East North Africa) region, which hosts another $39 \%$.

Among the GCC states, Saudi Arabia is the undisputed leader with 35\% of the GCC states' share, followed by Kuwait (24,1\%), the U.A.E. (18,7\%), Bahrain (14,2\%) and Qatar (8\%). The importance of the GCC states is far from surprising since the initial rise of the IFS sector was closely linked to the presence of petrodollars, which were (and are) of course plentiful in the Gulf. Among the non-GCC states, Iran and Pakistan have intended to fully Islamize their economies, making all assets theoretically Shari'a compliant from the 1980s onwards (Khan and Mirakhor, 1990). In Iran the islamization of the entire banking system was closely related to the Islamic revolution in 1979. The process has proved to be successful since Iran alone accounts for about 235 billion US $\$$ of Shari'a complaints assets (i.e. $100 \%$ of all Iranian assets ${ }^{5}$ ), almost as much as the GCC states in total and ca. $36,8 \%$ of the global total. In Pakistan, however, only a 
quarter (15 billion US\$) of all financial assets was Shari'a compliant in 2007, while in 2008 this amount has further dropped to 6,3 billion US\$. The Pakistani government seems to have shifted ideas onto the development of an Islamic financial sector parallel to the existing interest-based circuits (see Bekkin, 2007a: 123-4).

Table 2 Geographical distribution of Shari'a compliant assets (based on The Banker, 2008: 22, 24)

\begin{tabular}{|lcc|}
\hline \multicolumn{2}{c}{ Shari'a compliant assets (bn US\$) } & Percentage of total \\
\hline World regions & & \\
\hline GCC & 262,7 & 41,2 \\
Non-GCC MENA & 247,6 & 38,9 \\
Asia & 86,2 & 13,5 \\
Australia/Europe/N. America & 34,5 & 5,4 \\
Sub-Saharan Africa & 6,4 & 1,0 \\
Global TOTAL & 638,3 & 100,0 \\
\hline Within GCC & & \\
\hline Saudi Arabia & 91,9 & 35,0 \\
Kuwait & 63,3 & 24,1 \\
UAE & 49,1 & 18,7 \\
Bahrain & 37,3 & 14,2 \\
Qatar & 21,0 & 8,0 \\
GCC TOTAL & 262,7 & 100,0 \\
\hline
\end{tabular}

Second, to refine our level of analysis, we focus on the geographical location of the major players in the IFS sector. Table 3 provides a list of the 50 largest IFS firms that are located both within the Middle East and beyond. As Table 3 shows, the IFS sector is dominated by firms from the Middle East, mainly located in the GCC states and Iran. If one focuses on the top firms in terms of headquarters location, it appears that a relatively small number of cities plays a crucial role within these 'core' Shari'a compliant regions. Figure 2, which plots the headquarter locations of the top 100 IFS firms, shows that the IFS sector within the Middle East is indeed anchored in a small number of cities. Tehran has the largest headquarter presence with twelve top 100 firms $^{6}$, but the lion's share of these firms are non-listed government-owned institutions (e.g. the top 2 firms Bank Melli and Bank Saderat). Within the GCC states, top cities such as Manama and Kuwait City are leading the way, followed by other regional centres such as Dubai, Doha, and Abu Dhabi. In contrast to the Iranian situation, the IFS sector in GCC states has a rather different character, since it is much more based on private capital, while a lot of the firms are listed on one or more stock exchanges. Moreover, while Iranian firms generally have a domestic character, targeting the national retail market, Manama and Dubai are turntables in a more global strategy, hereby connecting other cities - both inside and outside the Middle East - into Islamic markets (see Bassens et al., 2010).

As Table 3 shows, the IFS sector is dominated by firms from the Middle East, mainly located in the GCC states and Iran. If one focuses on the top firms in terms of headquarters location, it appears that a relatively small number of cities plays a crucial role within these 'core' Shari'a compliant regions. Figure 2, which plots the headquarter locations of the top 100 IFS firms, shows that the IFS sector within the Middle East is indeed anchored in a small number of cities. Tehran has the largest headquarter presence with twelve top 100 firms $^{6}$, but the lion's share of 
these firms are non-listed government-owned institutions (e.g. the top 2 firms Bank Melli and Bank Saderat). Within the GCC states, top cities such as Manama and Kuwait City are leading the way, followed by other regional centres such as Dubai, Doha, and Abu Dhabi. In contrast to the Iranian situation, the IFS sector in GCC states has a rather different character, since it is much more based on private capital, while a lot of the firms are listed on one or more stock exchanges. Moreover, while Iranian firms generally have a domestic character, targeting the national retail market, Manama and Dubai are turntables in a more global strategy, hereby connecting other cities - both inside and outside the Middle East - into Islamic markets (see Bassens et al., 2010).

Especially Manama, which has been known to be a regional offshore banking centre for some decades, is now increasingly aiming at becoming the regional hub for IFS (see Bassens et al., 2010). Although Bahrain's share in terms of Shari'a compliant assets is relatively small (see Table 2), its importance is illustrated by the presence of no less than fifteen headquarters of the top 100 IFS firms. Although these remain small in comparison to the Tehran-based firms, their presence coincides with crucial institutions such as the Accounting and Auditing Organization for Islamic Financial Institutions (AAOIFI), the Liquidity Management Centre (LMC), the International Islamic Financial Market (IIFM), and the Islamic International Rating Agency (IIRA) which share presence there. Furthermore, 10 of the 40 companies on the Bahrain Stock Exchange are IFS firms, including top companies such as Al Baraka Banking Group, ABC Islamic and Ithmaar Bank. To develop Manama's competitive Islamic edge, the Central Bank of Bahrain has introduced a regulatory framework for monitoring and supervision that reflects the specific needs and concepts of Islamic finance (ICMA Centre, 2008: 33).

Dubai is also competing for its share. The Dubai Financial Market (DFM) is a key trading place for IFS firm's stocks in the region, currently listing 13 IFS firms on a total of 63 companies. The emirate has also set up the Dubai International Financial Center (DIFC), offering foreign investors an attractive fiscal and legal environment to set up their corporations. However, the Dubai International Financial Exchange (DIFX), which falls under the DIFC's authority, appears unattractive for IFS firms. Only one IFS firm (i.e. Al Baraka Banking Group) is listed there, a situation which is likely due to the incompatibility of the common law based legal environment within the DIFC and the Shari'a orientation of the IFS firms (see Caballo, 2007). But still, IFS are highly important in the Dubai market, since 12 of the 42 current DIFX listings are sukūk, predominantly issued to finance major infrastructure projects. For instance, the semigovernmental investment corporations Emaar and Nakheel are using sukūk to raise funds for their major real estate projects. These sukūk are Shari'a compliant asset-backed notes. A common securitization technique is to sell the assets to a Special Purpose Vehicle (SPV) and then to lease them back on an ijara basis (ICMA Centre, 2008: 55-6). The sukūk holders in turn receive periodic payments on a variable profit-and-loss sharing basis, instead of receiving a fixed interest rate. 
Table 1 The Top 50 IFS firms, with headquarters location and value of Shari'a-compliant assets (based on The Banker, 2008)

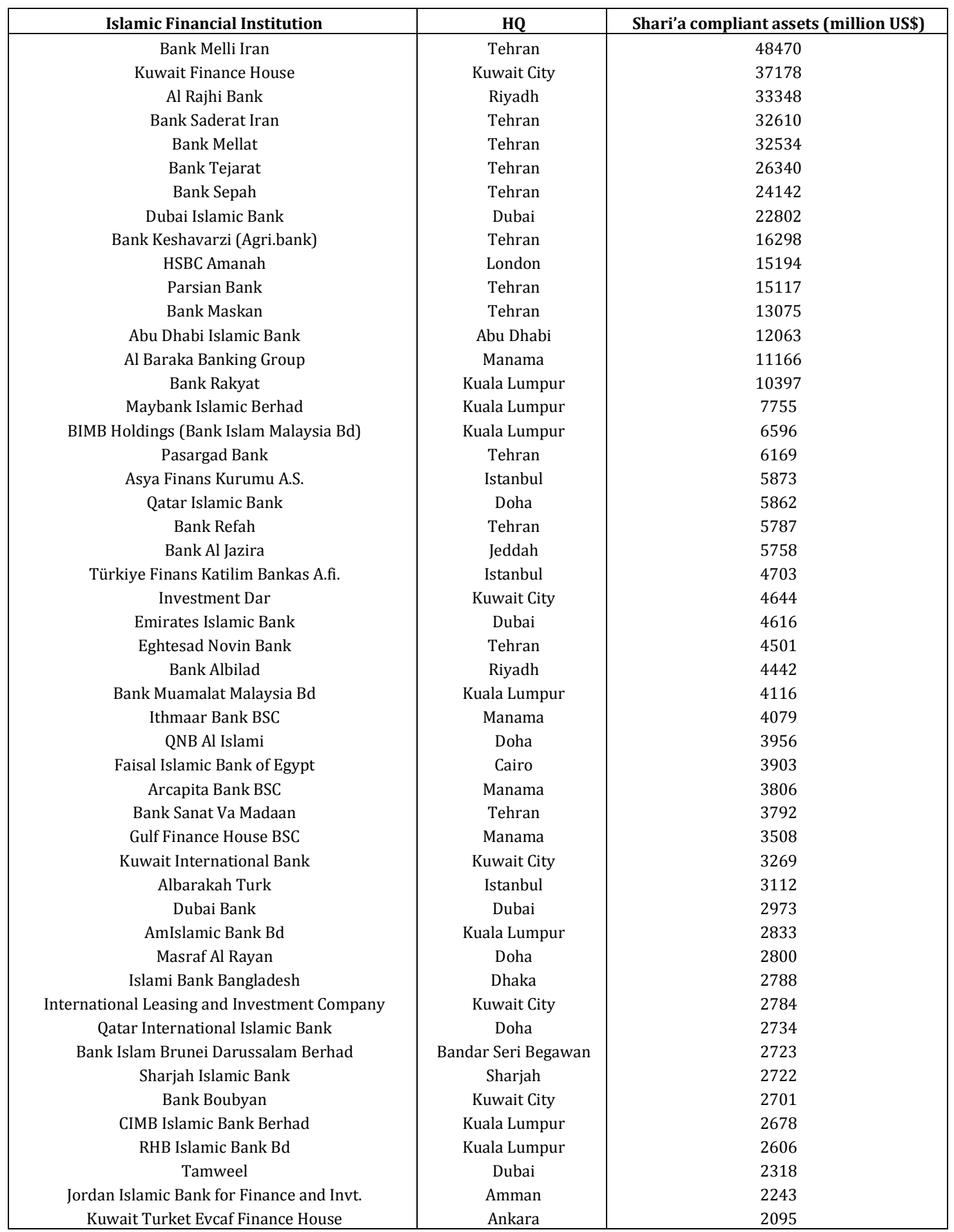




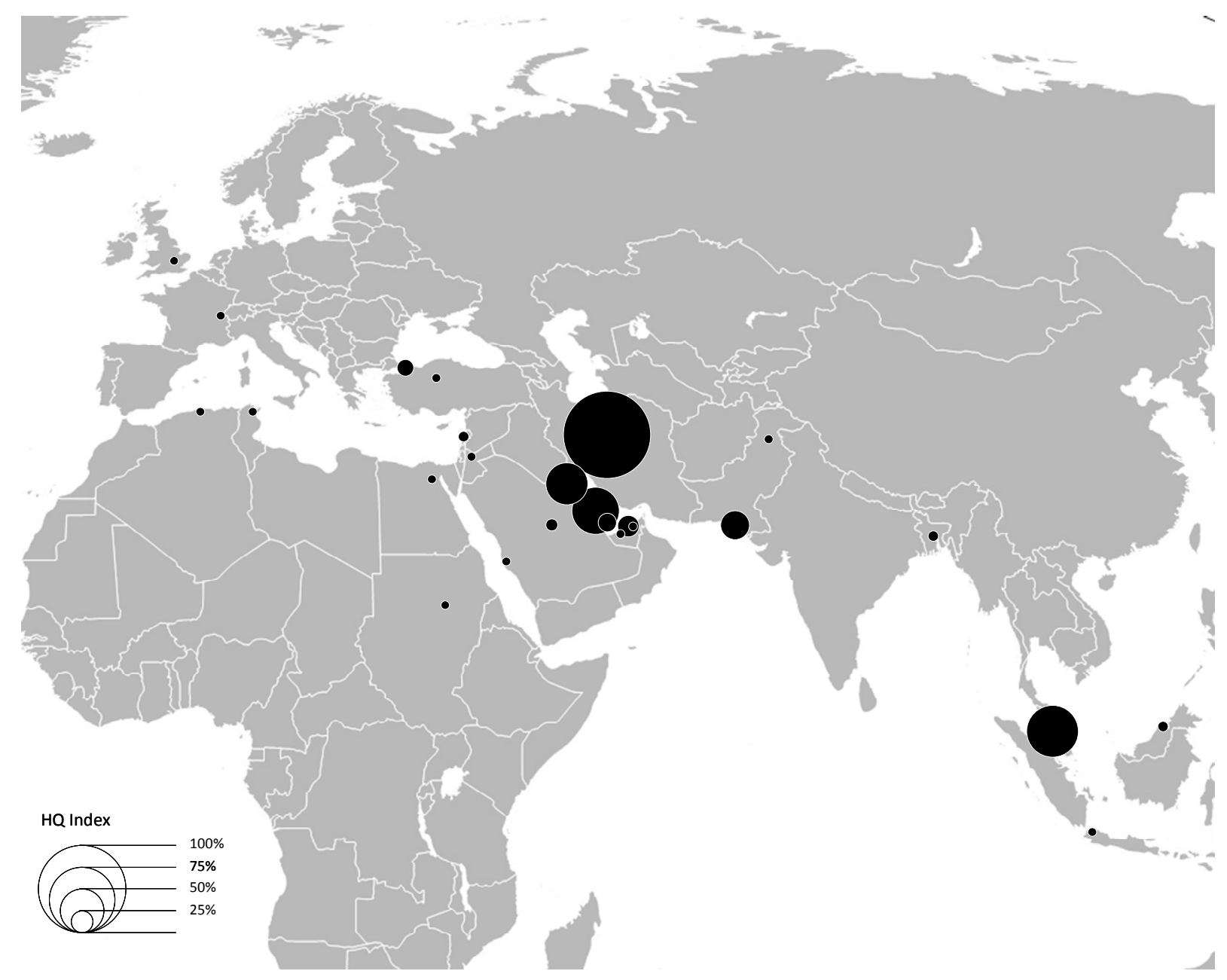

Figure 1 Top IFS centers: cities are presented on an HQ index, representing the aggregate of the HQ presence of the top 100 IFS firms (based on The Banker, 2007), weighted by asset value.

Outside the Middle East, Malaysia is the leader in terms of Shari'a compliance, holding approximately 67 billion US\$ of Shari'a compliant assets. Malaysia currently pursues a proactive policy towards the IFS sector, especially encouraging takaful services throughout the country via tax breaks and other deregulatory measures already outlined in the Takaful Act of 1984 (see Bekkin, 2007a: 127). According to the IMF (2007), Malaysia also hosts the largest sukūk market, estimated at 47 billion US\$ in 2007, which accounts for about two thirds of the global Islamic bonds outstanding and represents the largest market in terms of outstanding size and number of issues. In 2008, the central bank estimated the sukūk market already at 100 billion US\$, which is illustrative for its tremendous growth and popularity in Malaysia. In addition, in 2008, the 843 Shari'a compliant stocks accounted for $85 \%$ of the stocks listed in the domestic stock exchange (Reuters, 2008). The success of the IFS market is certainly a result of the supportive role of the Malaysian authorities. For instance, the Ninth Malaysia Plan (20062010) aims at strengthening Malaysia's position as a global IFS hub, as a centre for origination, distribution, trading, fund, and wealth management (IMF, 2007). By making the country a global Islamic brand, Malaysia is also trying to tap liquidity from the Gulf States. Evidently, much of this Islamic 'buzz' is located in Kuala Lumpur, which is home to ten of the top 100 IFS firms, but also to the Islamic Financial Services Board, an international standard-setting institution for Islamic finance. Simultaneously, the Malaysian offshore centre Labuan is developing IFS as a niche 
market to avoid competitive outbidding from other offshore financial centres (Abbott, 1999: 197, 208).

But also in non-Muslim countries, the IFS sector is now gaining momentum (see Bassens et al., 2010). IFS firms are present either through branch offices (e.g., Faisal Private Bank in Geneva, a subsidiary of the Manama-based Ithmaar Bank) or newly established full-fledged Islamic financial institutions (e.g., the Islamic Bank of Britain). Additionally, conventional financial institutions have opened Islamic 'windows' to cater to the local Muslim population (e.g. HSBC through its subsidiary HSBC Amanah). Other conventional banks such as Fortis Bank, Barclays, Deutsche Bank have not yet taken the step of opening up Islamic windows, but are slowly introducing some Islamic products (Shari'a compliant funds) into Western markets. Both in Europe and the USA Shari'a compliant products (mainly murabahah mortgages) are available on retail level. However, in terms of wholesale finance, Europe clearly has the upper hand with London and to a lesser extent Paris as IFS hubs on the rise. The fact that IFS developments in the USA are lagging behind is no doubt related to the more tense relations with the Middle East after the events of $9 / 11$ and the chain of events that was triggered in the aftermath. Notwithstanding New York's policy efforts in these markets and the influence of the Dow Jones Islamic Market Indexes, London is becoming the key player outside the Muslim world in the global Shari'a compliant market. As was the case for the Eurobond market a few decades ago, the London is again trying to become an 'entrepot' for global capital (ICMA Centre, 2008: 69), this time turning to IFS to get a share of the Gulf its excess liquidity. On a retail level, the UK Government has already made a number of legal adaptations such as the elimination of double stamp tax, which previously limited the attractiveness of Islamic mortgages. Most of these mortgages are structured according to the murabahah model. Unlike a conventional loan where the customer immediately becomes the owner of the commodity, the murabahah model implies a double ownership transfer: the first transfer occurs when the bank buys the commodity (e.g. a house) for the customer, followed by a second transfer when the last instalment is paid to the bank. Nowadays, thanks to legal adaptations, the double ownership transfer no longer leads to double taxation, enhancing the competitiveness of Islamic mortgages in the UK market. On the wholesale level, in order to channel the Gulf's Shari'a compliant investments through the City, the UK government is considering the issuance of government securities in sterling in suku $k$ form, which would provide a basis for active trading and for pricing of corporate securities. This would not only enhance the price-setting of the latter, the established structure would also reduce the cost of the corporate issuance itself (ICMA Centre, 2008: 70-71).

Seeing the progress London has made, Paris is anxious to attract some of the Gulf-based investments that are currently flowing to London. The Minister of Finance of France, Christine Lagarde, wants to offer a more accommodating legal and fiscal framework in France (Anonymous, 2008a). Although some IFS firms are already present (e.g. the Iranian Bank Melli and Bank Tejarat, the Bahraini ABC Islamic Bank), and the potential retail market is substantial and even bigger than in the UK, Paris is not (yet) a serious player in the global Shari'a compliant market.

In addition to these European cities, a number of Asian financial centres such as Singapore, Hong Kong and Tokyo are also turning their attention to the IFS market, albeit that they stand in the shadow of the Islamic giant Kuala Lumpur. These international financial centres are hoping to play an important role in the emerging IFS sector just as well. Tokyo, for instance, has made 
clear that it is considering the launch of a sukūk through the Japan Bank for International Cooperation (JBIC) (Anonymous, 2008b). However, the rather closed character of the Japanese market makes it unlikely for Tokyo to become a global Islamic hub in the near future. Singapore is already a step further. The city has already developed a Shari'a compliant market, although it is still very small. According to the central bank, in 2007 Singapore had about 1.32 billion US\$ of Shari'a compliant property funds and 500 million US\$ of takaful funds (International Herald Tribune, 2007). In the case of Hong Kong, the IFS sector is still embryonic, seeing that only this year the first Islamic bank (Hong Leong Bank) has opened an Islamic window in the city.

\section{Conclusion}

Whereas the actual size of the Shari'a compliant market is still small in relative terms, the growth rate of the IFS sector and its huge potential Muslim costumer basis globally indicates that this could turn out to be a crucial evolution within the international financial markets. Especially within the Muslim world, the IFS sector is increasingly becoming the 'appropriate' way of banking, financing projects and getting insurance. At the same time, the developing retail market forms the basis for international Islamic markets, where Islamic bonds are being issued and traded in centres of which Manama, Dubai and Kuala Lumpur are prime examples.

While the IFS sector is going global to cater to Muslim customers in both Muslim and nonMuslim countries on a retail level, the wholesale Shari'a compliant markets are also attracting the interest of 'conventional' international financial centres worldwide such as London, New York, Singapore, etc. Given the high (albeit volatile) oil prices and the Islamic economic revival in the Middle East, these centres are gradually coming to realise that the capacity to attract investments from the Gulf will be a crucial factor in their overall competitiveness in the years to come. Indeed, under the conditions of the contemporary financial crisis, both the nature and the geography of the international financial market are likely to be reshaped intensely (Taylor et al., 2009). Given its steep rise and popularity, the IFS sector may very well be the vanguard of a next generation of globalization, where international financial markets are organized both more ethically and perhaps more cautiously.

\section{Notes}

1. The Muslim World is here defined as the geographical region that comprises all countries with a Muslim majority, stretching from North Africa, over the Greater Middle East to South-East Asia.

2. The Dubai Islamic bank, the first private interest-free bank, was set up in 1975 (Zaher and Hassan 2001: 169).

3. As a reference: On July $21^{\text {st }}, 2008$, the KBC Group, the third largest Belgium-based and $38^{\text {th }}$ ranked bank worldwide, alone had an asset value of about 517 billion US\$ (see Fortune, 2008).

4. The hadiths are a collection of written down traditions, concerning the actions and sayings of the Prophet Mohammed.

5. However, as Bekkin (2007b: 124) has pointed out, this percentage is merely theoretic, as the Iranian economy knows the use of interest-based modes of finance (e.g. Eurobonds) as well. 
6. The top 100 full-fledged IFS firms were selected from The Banker's Top 500 Islamic Financial Institutions (November 2007 supplement).

\section{References}

Abbott, J. P. (1999) Labuan: treasure island, pet project or ghost town? In Offshore financial centers and tax havens: The rise of global capital, M.P. Hampton, P.A Abbott (Eds.), pp. 192211, New York: Palgrave MacMillan.

Akacem, M., Gilliam, L. (2002) Principles of Islamic banking: Debt versus equity financing. Middle East Policy, 9 (1), pp. 124-138.

Ala Hamoudi, H. (2007) You say you want a revolution: interpretive communities and the origins of Islamic finance. Virginia Journal of International Law, 48 (2), pp. 249-306.

Anonymous (2008a) France to promote Islamic finance. Retrieved October 16, 2008, from http://www.expatica.com/fr/main.html.

Anonymous (2008b) Will Tokyo become an Islamic finance hub? Retrieved October 17, 2008, from http://news.efinancialcareers.sg/News_ITEM/newsItemId-13509.

Bassens, D., Derudder, B., Witlox, F. (2010) Searching for the Mecca of finance: Islamic financial services and the world city network. Area, 42 (1), pp. 35-46.

Bekkin, R. I. (2007a) Islamic insurance: national features and legal regulation. Arab Law Quarterly, 21 (1), pp. 3-34.

Bekkin, R. I. (2007b) Islamic insurance: national features and legal regulation. Arab Law Quarterly, 21 (2), pp. 109-134.

Caballo, A. (2007) The law of the Dubai International Financial Centre: common law oasis or mirage within the UAE? Arab Law Quarterly, 21 (1), pp. 91-104.

Fortune (2008) Global 500. Retrieved September 19, 2008, from http://money.cnn.com/magazines/fortune/global500/2008/index.html.

Goldberg, E. (2004) Marketing commodities does not happen on commodity markets: the Egyptian Bursat Al-'Uqud and oil futures markets. In The Politics of Islamic Finance, M. Clement, R. Wilson (Eds.), pp. 81-103, Edinburgh: Edinburgh University Press.

Hefner, R. W. (2006) Symposium visible hands, religion and the market: Islamic economics and global capitalism. Society, 44 (1), pp. 16-22.

ICMA Centre (2008) The competitive position of the Gulf as a global financial centre. Retrieved October 15, 2008, from http://www.cityoflondon.gov.uk.

International Financial Services London (2008) IFSL Research: Islamic Finance 2008. Retrieved September 8, 2008, from http://www.ifsl.org.uk/research.

International Herald Tribune (2007) Singapore to cultivate Islamic finance sector. Retrieved October 17, 2008, from http://www.iht.com/articles/2007/05/17/news/sxislamic.php.

International Monetary Fund (2007) Malaysia: An Islamic Capital Market Hub. Retrieved October 15, 2008, from http://www.imf.org.

Iqbal, M., Molyneux, P. (2005) Thirty Years of Islamic Banking: History, Performance and Prospects. New York: Palgrave Macmillan.

Khan, M.S., Mirakhor, A. (1990) Islamic banking: experiences in the Islamic republic of Iran and Pakistan. Economic Development and Cultural Change, 38 (2), pp. 353-375.

Kuran, T. (1995) Islamic economics and the Islamic subeconomy. Journal of Economic Perspectives, 9 (4), pp. 155-173.

Kuran, T. (1997) The genesis of Islamic economics: a chapter in the politics of Muslim identity. Social Research, 64 (2), pp. 301-338. 
Naughton, S., Naughton, T. (2000) Religion, ethics and stock trading: The case of an Islamic equities market. Journal of Business Ethics, 23 (2), pp. 145-159.

Pollard, J., Samers, M. (2007) Islamic banking and finance: postcolonial political economy and the decentring of economic geography. Transactions of the Institute of British Geographers, 32 (3), pp. 313-330.

Reuters (2008) Malaysia widens sharia-compliant stock list. Retrieved October 15, 2008, from http://www.reuters.com.

Sanhuri, A. (1967) The Sources of Authority in Islamic Jurisprudence: A Comparative Study with Western Jurisprudence. Vol. 3 (14). Cairo.

Siddiqi, N. (2007) Shari'a, economics, and the progress of Islamic finance: the role of Shari'a experts. In Integrating Islamic finance into the mainstream: Regulation, standardization and transparency, S. Nazim Ali (Ed.), pp. 99-107, Cambridge: Harvard Law School.

Sudin, H., Norafifah, A., Planisek, S. L. (1994) Bank patronage factors of Muslim and non-Muslim customers. International Journal of Bank Marketing, 12 (1), pp. 32-40.

Taylor, P. J., Ni, P., Derudder, B., Hoyler, M., Huang, J., Lu, F. Y., Pain, K., Witlox, F., Yang, X, Bassens, D., Shen, W. (2009). The way we were: command-and-control centres in the global space-economy on the eve of the 2008 geo-economic transition. Environment and Planning A, 41 (1), pp. 7-12.

The Banker (2007) Top 500 Islamic Financial Institutions. November supplement, London: The Banker.

The Banker (2008) Top 500 Islamic Financial Institutions. October supplement, London: The Banker.

Tripp, C. (2006) Islam and the Moral Economy: The Challenge of Capitalism. Cambridge: Cambridge University Press.

Vogel, F. E., Hayes, S. L. (1998) Islamic Law and Finance: Religion, Risk and Return. The Hague: Kluwer Law International.

Warde, I. (2000) Islamic Finance in the Global Economy. Edinburgh: Edinburgh University Press.

Yousef, T. M. (2004) The murabaha syndrome in Islamic finance: laws, institutions and politics. In The politics of Islamic finance, M. Clement, R. Wilson (Eds.), pp. 63-80, Edinburgh: Edinburgh University Press.

Zaher, T. S., Hassan, M. K. (2001) A comparative literature survey of Islamic finance and banking. Financial Markets, Institutions \& Instruments, 5 (4), pp. 155-199. 
